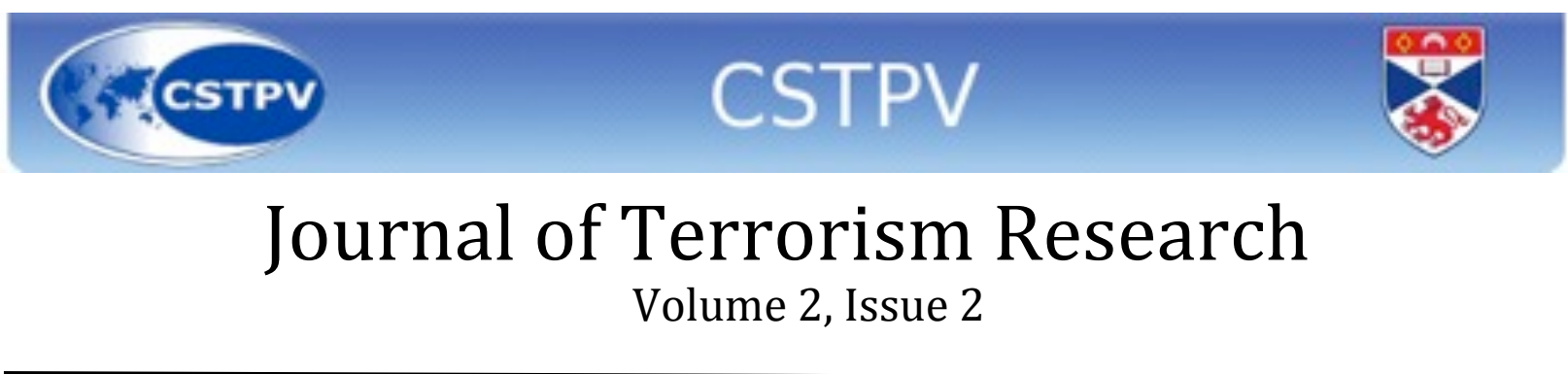

\title{
The Impact of Food Consumption, Government Type and Effectiveness, on the Rate of Somali Maritime Piracy, 2000-2008
}

\author{
by Sam Rohrer
}

\section{Abstract}

The analysis of maritime piracy off the Horn of Africa is still a developing area of academic research. The work that has been conducted to date has remained largely qualitative. Two recurring assumptions made but not empirically tested in this area of research are 1) the perceived link between government stability and the rate of maritime piracy, and 2) drought conditions implying food shortages in Somalia, and their impact on the rate of maritime piracy off the Horn of Africa The findings of this project show a strong increase in maritime piracy following the transition from assorted Islamic Courts to the Transitional Federal Government (TFG). However, variations in the consumption of staple foodstuffs, and an index of the World Bank Governance Indicators do not have a significant impact on the frequency of maritime piracy in the region. If maritime piracy off the Somali coast is to be eliminated, rather than policed, efforts should be made to encourage the development of governmental institutions that utilize culturally-respected institutions supported by the local populace.

\section{Introduction}

Maritime piracy in the Straits of Malacca and off the Horn of Africa has been a recurring topic in the realm of government case studies and think tank analyses. From 2000 on it has gradually emerged as a topic of interest in scholarly academic articles. The majority of the existing work on maritime piracy, regardless of position, is qualitative; there are few quantitative articles addressing modern maritime piracy. The quantitative studies that have been conducted find that maritime piracy is not random; the type of ship and flag it flies are statistically significant factors[1], and as governmental stability shifts from weak to failed, there will be an increase in the rate of kidnappings as compared to theft of property due to the degradation of transportation infrastructure[2].

Two recurring assumptions made, but not empirically tested, in the literature are 1) the perceived link between government stability and the rate of maritime piracy[3],[4],[5], and 2) drought conditions, implying food shortages, in Somalia, and their impact on the rate of maritime piracy off the Horn of Africa[6],[7]. This project rectifies this issue by quantitatively testing the impact of the transition from assorted Islamic Courts to the Transitional Federal Government (TFG), an 


\title{
Journal of Terrorism Research
}

\author{
Volume 2, Issue 2
}

index of the World Bank Governance Indicators, and staple food consumption on the rate of maritime piracy off the Somali coast. The findings of this project make a significant contribution to the field because they find a statistically significant link between the transition from Islamic Courts to the TFG and the rate of maritime piracy off the Somali coast; and a statistically insignificant relationship between the consumption of staple food stuffs, and the World Bank Governance Indicators on the rate of maritime piracy off the Somali coast.

\section{Causes of Piracy}

Before the broader questions regarding modern maritime piracy can be debated, one must first ask, what are the sources that lead to the development of modern maritime piracy, and are they any different from the sources of historical maritime piracy? To answer the latter half of this question, there does not appear to be a significant difference in the causes of piracy that are unique to any particular point in history. There are likely many factors that contribute directly or indirectly: civil war, war, poverty, maritime experience, etc. However, there are four broad criteria that are generally present: 1) desperation, 2) opportunity, 3) sanctuary, and 4) leadership[8].

Historically, individuals who turn to piracy have done so in an attempt to avoid a Hobbesian life, which is dull, nasty, brutish, and short. In doing so, they achieve wealth and potentially some degree of fame[9],[10]. This initial condition has held true from the Illyrian pirates prior to Roman annexation, to the American colonies in the 1500s, through to contemporary Somalia and Aceh. The desire for economic gain suggests that pirates are rational actors acting in their own self-interests, and capable of sound cost-benefit decision making. The second criterion opportunity - exists when an individual has either seagoing experience or access to port communities with sufficient commercial traffic to target. The third - sanctuary - is vital. In order to launch naval raids, pirates require sympathizers, protectors, financiers, and commercial outlets for stolen goods or hostages, and generally some level of tolerance by the local government[11]. Finally, after these criteria are met, maritime piracy can lead to the development of sophisticated local economies, with the protection of local political figures, and capable of supporting small armadas[12].

In recent years, piracy has developed into a highly lucrative trade; in 2007 the average ransom for a ship has been estimated at $\$ 800,000$, increasing to $\$ 1,600,000$ per ship by the end of 2008 , reaching as high as $\$ 2,500,000$ in early 2009[13],[14]. The apparent economic success of Somali piracy has led to the development of an extensive network of negotiators, spokesmen, logistic coordinators, and financial launderers[15],[16]. 


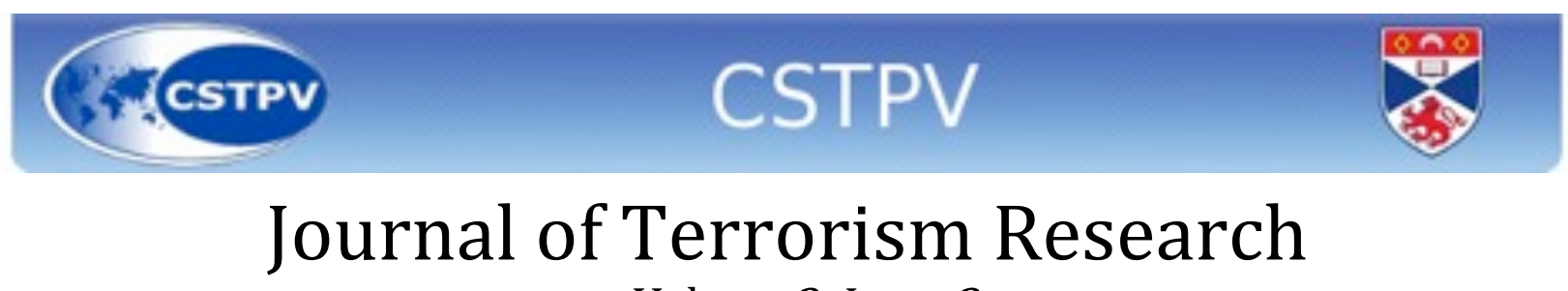

Volume 2, Issue 2

Similar Causes: Piracy and Terrorism

In addition to maritime piracy, the motivating factors of desperation and opportunity have been applied in research explaining the recruitment, and efficacy of terrorist organizations. Blomberg et. al. found that economic contractions are positively correlated with increases in terrorist violence[17]. Honaker disaggregated Catholic and Protestant data in Ireland, and found that increases in Catholic unemployment led to increases in Republican violence, and increases in Protestant unemployment led to increases in Loyalist violence[18]. Sufficient economic contractions and increases in unemployment create a sense of desperation within certain levels of a society. The differentiating factor between desperate individuals resorting to maritime piracy in Somalia as compared to terrorism in Ireland can be attributed to opportunity. Somalia possesses a unique combination of traits: a collapsed state located near vulnerable sea lanes, a desperate coastal population with sea faring experience seeking economic relief from a bleak situation, and a relative dearth of terrorist organizations that could provide financial incentives for joining immediately following the collapse of the Barre government in 1991. Whereas in Ireland a stable and effective state apparatus remained in place, the volume of maritime trade was lower and less vulnerable, and desperate individuals could join an established well-funded terrorist organization in an attempt to rectify the perceived wrongs that led to their desperate state of being.

\section{Governmental Collapse and the Emergence of Piracy in Somalia}

The romanticized image of the pirate pillaging at sea, with no ties to land or civilization outside of the confines of the ship, is clearly a fallacy. As discussed in the root causes of piracy, ports of call are required for any maritime raid. Thus, the ability of government to exert control over territory effectively, and reduce or eliminate conditions that encourage criminal activity, is vital. In this sense, piracy is no different from land-based smuggling or bootlegging operations. This position has been repeatedly stressed in the existing literature[19],[20].

The fluctuating environment that allowed piracy to develop along the Somali coast has been linked to the collapse of the government of Siad Barre in 1991. Barre's government ceased functioning following clan-based power struggles that began in 1988. The state of Somalia proceeded to fracture into three primary zones. The eastern coastline, occupying the territory of the former Italian Somaliland, split into the semiautonomous region of Puntland in the north and the southern portion of the nation, including the capital Mogadishu, has remained a conflictprone region. From 2000-2005 an assortment of Islamic courts came into existence and served as a form of domestic government, and criminal court system[21]. In 2006 a formal government based on this system, called the Islamic Courts Union (ICU), was implemented; it governed the majority of this region until the end of the year, with a degree of popular support[22]. At this 


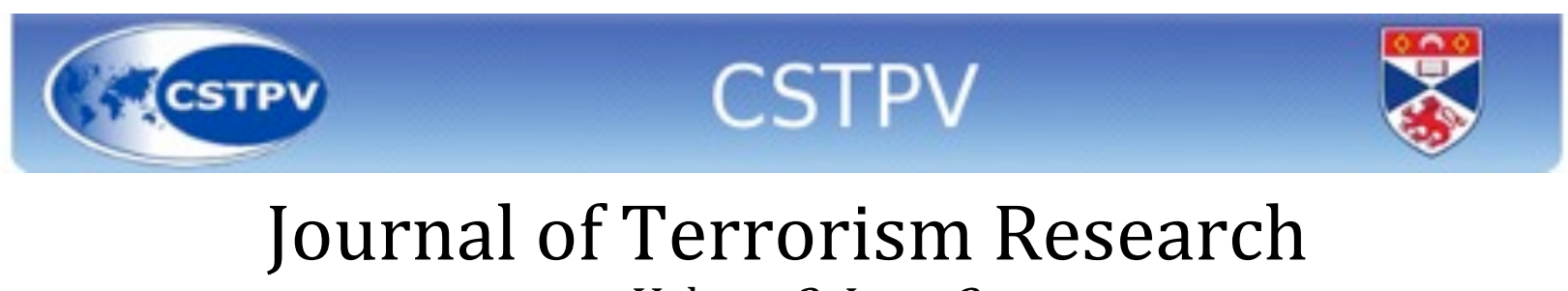

Volume 2, Issue 2

point the TFG, supported by the Ethiopian government, supplanted the ICU, and sought to establish the Western-backed TFG as the legitimate governing authority in Somalia[23]. The northern portion of the country, Somaliland, considers itself independent. Contrary to the rest of Somalia, this region is relatively stable, and has developed a government combining Western democratic structures with local clan-based hierarchies[24].

The TFG has encountered difficulty establishing itself as the legitimate national government. This is in part due to unique cultural traits of the Somali identity. A cautious attitude towards outsiders is a common theme, illustrated by Somali fishing communities turning to piracy after initially protecting Somali waters from foreign dumping and fishing[25],[26]. The hierarchy of priorities, expressed in an old Somali proverb, suggests that resisting outside forces is a cause to which most Somalis should rally, overlooking existing clan and family-based disagreements. If this attitude has carried into the contemporary Somali identity, it could explain why foreign efforts to reduce criminal activity/maritime piracy, and encourage the development of the TFG, have met with resistance.

Me and my clan against the world. Me and my family against my clan. Me and my brother against my family. Me against my brother[27].

\section{Somali Piracy: Unique Threat and Links to Terrorist Organizations}

Piracy hotspots exist throughout the globe, so why is Somali piracy considered to be potentially more troublesome than that of the Gulf of Guinea or South China Sea? Unlike piracy in other regions, the range of operations for Somali pirates has increased markedly. Previously focused on the strategic chokepoint of the Gulf of Aden, Somali pirates now operate deep into the West Indian Ocean in an area that is estimated to cover 1-2.5 million square miles[28],[29]. The large range of operations, and Somalia's "failed state" status, create a nexus of concern for security analysts when the issue of terrorism is considered. The worst-case scenario is the emergence of a government that is strong enough to control piracy, but chooses not to control it, and stable enough to provide protection for Islamist terrorist organizations[30].

The legitimacy of this fear is a recurring topic of debate in the field. In the 2008 Rand Corporation report, The Maritime Dimensions of International Security, and the 2009 Danish Institute for International Studies report Piracy Terrorism, and Naval Strategy, maritime pirates and terrorists are defined as entirely separate actors. Terrorists are motivated for some higher political cause, and pirates are motivated by financial gain. At a base level this distinction is intuitive. However, it overlooks the commonalities shared by terrorists and maritime pirates. 




As discussed in the Council of Foreign Relations article "Combating Maritime Piracy," there are two key areas where piracy and terrorism overlap, legal classification and financial ties. First, both groups operate independently of a nation-state, target civilians, and commit acts of homicide and destruction for private ends[31]. Second, evidence exists that pirates have provided funding for terrorist organizations in Somalia and Indonesia[32]. Despite different long-term goals, there is room for collaboration. Maritime piracy can provide radical Islamists with funds to launch terrorist attacks[33]..A potential example of such collaboration was the hijacking of a Greek-owned cargo ship in September 2008. Following seizure it was directed south to a port controlled by Islamists, rather than to an existing pirate base on the Somali coast[34].

\section{Research Questions}

Based on the existing literature, two common assumptions surrounding Somali piracy are the perceived links between government stability and food consumption, with the rate of maritime piracy off the Horn of Africa. In an attempt to quantitatively examine these issues, the following hypotheses will be tested.

H1: As governmental authority decreases the frequency of maritime piracy along the coast of Somalia will increase.

H2: Domestically developed governments incorporating culturally respected institutions will be more effective in decreasing the frequency of maritime piracy along the Somali coast.

H3: When reductions in national food consumption occur, the frequency of maritime piracy along the coast of Somalia will increase.

\section{Dependent Variable}

Piracy data was compiled from the International Maritime Organization's (IMO) quarterly reports, specifically, by combining events of piracy and armed robbery against ships that were allegedly attempted, and-allegedly committed, in the region of East Africa from 2000 through 2008. This region was selected because it encompasses attacks along the Somali coast. As previously discussed, piracy is a transnational crime and some Somali pirates now operate well into the Indian Ocean. This is a region also tracked in the IMO reports; the majority of attacks in this region are along the coast of the Indian subcontinent, and it seems unlikely to be associated with Somali piracy. Regarding attacks located further from shore, it would be difficult to determine the originating port of the pirate crew. While pirate bases may exist in other countries in East Africa, the majority of the documented operations are launched from Somali ports. 


\section{Journal of Terrorism Research}

\section{Volume 2, Issue 2}

Additionally, attempted but unsuccessful events of piracy are still relevant when looking at the phenomenon at a regional level.

There are concerns regarding the accuracy of this data. Many shipping companies choose not to file a report regarding a pirate attack so long as the financial and human losses are not high. Underreporting occurs for two main reasons. First, reporting instances of piracy can increase a shipping company's insurance premiums. Second, slowing vessels to complete a formal report can lead to delays in the delivery date of cargo. Thus, some shipping firms prefer to sidestep the process. This has led to claims that statistics regarding maritime piracy may be underreported by as much as 50 percent[35],[36].

\section{Independent Variables}

Two measures of government, and one measure of food consumption, will be used in this paper. The first will be measured using the World Bank Governance Indicators. The second, will be a dichotomous variable noting the differences between the TFG formed in exile, and the domestically developed Islamic courts systems. The third independent variable will measure domestic food consumptions in Somalia from 2000-2008.

The World Bank Governance Indicators is a desirable measure, because it is released annually for more than 200 countries. The measure contains six components: 1) "voice and accountability" (the ability of the citizenry to express views and interests, and play a role in selecting the leading figures of their government), 2) political instability and violence, 3) government effectiveness, 4) regulatory burden, 5) "rule of law" (the principle that every member of society must follow the law), and 6) control of corruption[37]. All six of these indicators are scaled in the same manner on a five point scale, and globally ranked by percentile. In order to achieve a single score for each year, the percentile ranking of these six factors will be averaged together into an overall "good governance" indicator, which will be referred to as, the World Bank Governance Index (WBGI) (see tab. 1). Data is available for every year analyzed, 2000-2008, with the exception of 2001. For this period, an average of the 2000 and 2002 indicators will be used.

The dichotomous ICU/TFG variable includes the Shari'a Implementation Council (2000-2003), the Supreme Council of Islamic Courts of Somalia (2004-2006), and the Islamic Courts Union (2006) to create a variable that is representative of the increasing prevalence and governing effectiveness of Islamic institutions prior to the TFG from 2000 Q1 until 2006 Q4[38],[39]. The TFG is considered in power or ascendant from the 2007 Q1 until 2008 Q4. While the TFG continued to face resistance from elements of ICU splinter groups, Harakat Al-Shabaab Mujahideen in particular, the TFG was 


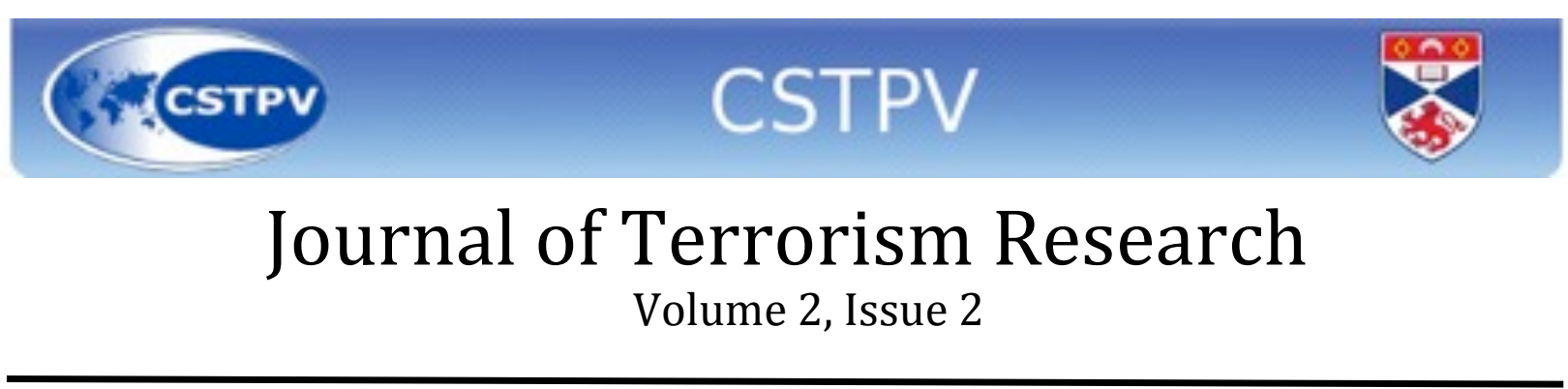

considered nominally in control of the institutions of government until Ethiopia's withdrawal of military support in 2009[40]. This variable allows for a measure of maritime piracy, both, before and after a clear transition in forms of government.

Food consumption data was collected from Index Mundi, and is based on U.S. Department of Agriculture data[41],[42],[43]. While a variable for total food consumption is not available, consistent data is available for estimated national consumption of wheat, corn, and milled rice for the years 2000-2008. The unit of measure used for the domestic consumption of these three staple foodstuffs is measured in increments equal to 1000 metric tons. Data for these three staple food types will be merged to form a quarterly 'staple food' variable. Food shortages are likely linked to either 1) drought conditions, or 2) dramatic fluctuations in the price of agricultural products within the country. Both could contribute to a weaker government, and encourage more individuals to turn to maritime piracy, but maritime piracy seems unlikely to directly impact drought or food consumption within Somalia.

\section{Tests}

The impact of the independent variables - WBGI, the ICU/TFG variable, and measure of domestic food consumption - will be tested using a one-tailed negative binomial regression to determine their impact on the dependent variable: the quarterly incidences of maritime piracy. This method of regression is appropriate when a variable is a "count" (tally of observed events), over-dispersed or under-dispersed, and each subject has the same length of observation. The negative binomial regression is preferable to other count models, such as an ordinary least square (OLS), Poisson, or zero-inflated model when these conditions are present. Count variables often follow a Poisson distribution, which requires the mean and variance to be somewhat similar. This distribution is not present in the dependent variable, which has a mean of 9.861 and a variance of 133.209. The variance of quarterly pirate attacks is nearly 14 times larger than the mean. The distribution is displaying signs of under-dispersion, that is, less variance than might be expected in a Poisson distribution. The quarterly data used in the dependent variable only has a single entry with a value of zero. Thus a zero-inflated model should not be run, as it required repeated entries with a value of zero.

First a standard negative binomial regression will be run in order to determine if the model as a whole is significant. The model will be considered significant if the probability of getting a chisquared statistic as extreme as that predicted under the null hypothesis, which would predict no relationship, is .05 or less. If the first regression is significant, it will be followed by a robust negative binomial regression. Using a robust negative binomial regression utilizes a more 


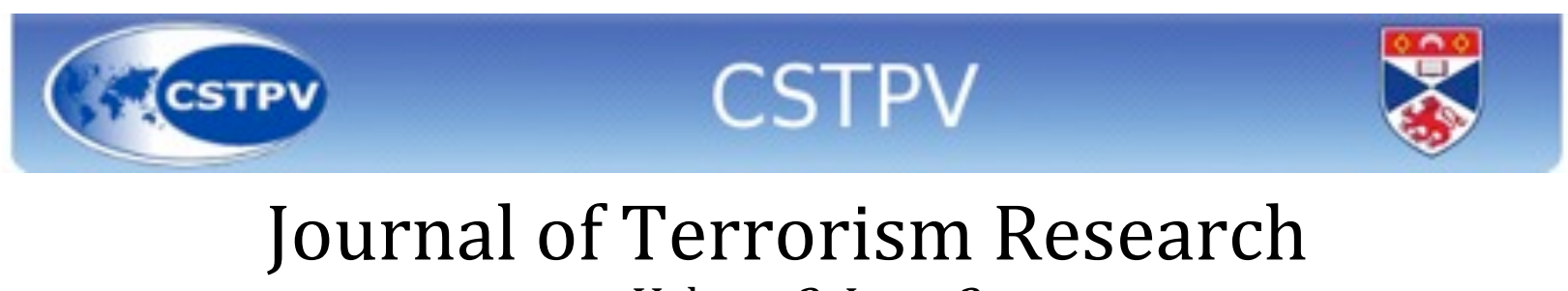

Volume 2, Issue 2

stringent set of standard errors for the coefficients used in the regression, and adjusts the model to account for heteroskedasticity. Utilizing the robust version of the regression will result in a change in the model chi-square. The chi-square statistic measures the "goodness of fit," meaning the ability of the observed data to deviate from those expected under the null hypothesis. Rather than a likelihood ratio chi-square, the robust negative binomial regression uses a Wald chisquare, which offers a more conservative chi-square estimate. The significance of the independent variables will be based on their z-score, which allows for the standardized comparison of variables with different metrics.

\section{Results}

The first negative binomial regression, run using the WBGI, ICU, and staple foods independent variables, against the quarterly incidences of piracy dependent variable, as a whole is statistically significant (see Table 2). The likelihood-ratio chi-square was 21.47 . The probability that the chisquare statistic could be the same as that predicted by the null hypothesis, which would expect no relationship between the variables, is 0.0001 . This is well within the five-percent-or-less criteria selected to determine the significance of the model as a whole. Additionally, the chi-bar squared with one degree of freedom is 81.56 . This confirms negative binomial regression as the appropriate test over other possible regressions. If the chi-bar squared statistic had been closer to zero, for example, a reading of fifty or less, it would suggest that a negative binomial regression would be an inappropriate regression model to use with these variables. Since the model as a whole is significant, the variables will be reanalyzed using the more stringent robust negative binomial regression.

The robust negative binomial regression resulted in an increase in the chi-square which is now a Wald chi-square, moving from 21.47 to 24.67 (see Table 2). This increase indicates that the "goodness of fit" has increased as well. The probability that the chi-square statistic could be the same as that predicted by the null hypothesis has decreased from 0.0001 to 0.0000 . The model as a whole remains significant. The variable coded for the transition from Islamic Courts governance to the TFG is significant, as the probability that the z-score is as extreme as that predicted by the null hypothesis is zero. The presence of the ICU results in a decrease of the coefficient equal to -0.165 . The WBGI variable is insignificant, as the probability that the $\mathrm{z}$-score for the variable could be predicted by the null hypothesis is 0.538 , that is, there is a $53.8 \%$ chance that the null hypothesis would predict a similar relationship. The staple food consumption variable is also insignificant, as the probability that the $\mathrm{z}$-score for the variable could be predicted by the null hypothesis is 0.485 , there is a $48.5 \%$ chance that the null hypothesis would predict a similar relationship. 


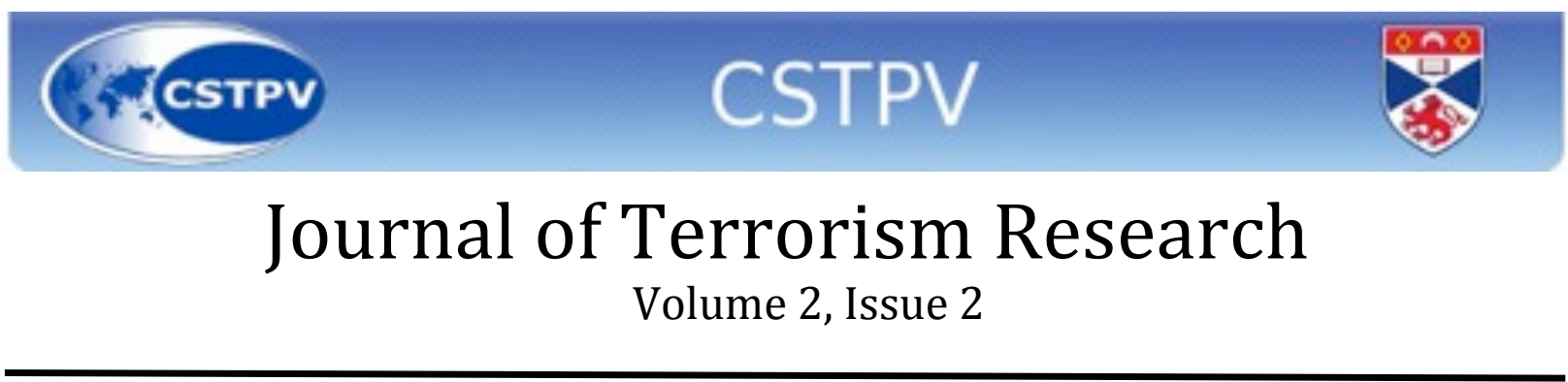

\section{Discussion of Results}

These results disprove $\mathrm{H} 3$, that domestic food consumption is significantly linked to maritime piracy off the Horn of Africa. They also disprove H1, that fluctuations in the WBGI impact maritime piracy. The predictive power of good government, as measured by the WBGI, is not statistically significant. This is clearly illustrated when the two years of TFG control 2007 and 2008 are compared to the last two years of Islamic Courts governance 2005 and 2006 (see Table 3). The TFG's WBGI ranged from .56-.63, and the ICU's WBGI ranged from .48-.65. During this period of time, under similar measures of governance, the Islamic Courts averaged 9.5 attacks per quarter, as compared to the 24.25 per quarter of the TFG.

However, the test results do confirm $\mathrm{H} 2$ in that that the grassroots-developed ICU was significantly more capable of controlling piracy as compared to the Western-backed TFG. The regression suggests that the ICU/TFG variable is capturing some element that influences the ability of government to control maritime piracy, that was present during the rise of assorted Islamic Courts (2000-2006), but not present during the TFG's period of ascendancy (2006-2008). Greater specificity, or additional controls, is not immediately available given the limited nature of data available regarding Somalia following the collapse of the Barre regime.

\section{Limitations}

There were multiple limitations to conducting these tests. Locating multiyear indicators of domestic crime, corruption, drought, and domestic income - the standard types of measures collected by most governments - was simply not possible. The data available from international governmental organizations and non-governmental organizations was frequently incomplete. For example, Transparency International's corruption index was only sporadically available. Therefore this research relies on information collected by foreign and international organizations that had consistent records ranging from 2000-2008, primarily the U.S. Department of Agriculture via Index Mundi, and the World Bank.

\section{Future Research}

The ability to conduct future quantitative research is dependent on consistent data, which may remain indefinitely unavailable. Recognizing that pirates are rational actors, it would be interesting to see if a link exists between some measure of income and the rate of piracy. The ability of pirates to maintain safe havens has also been linked to bribery. Additional annual 


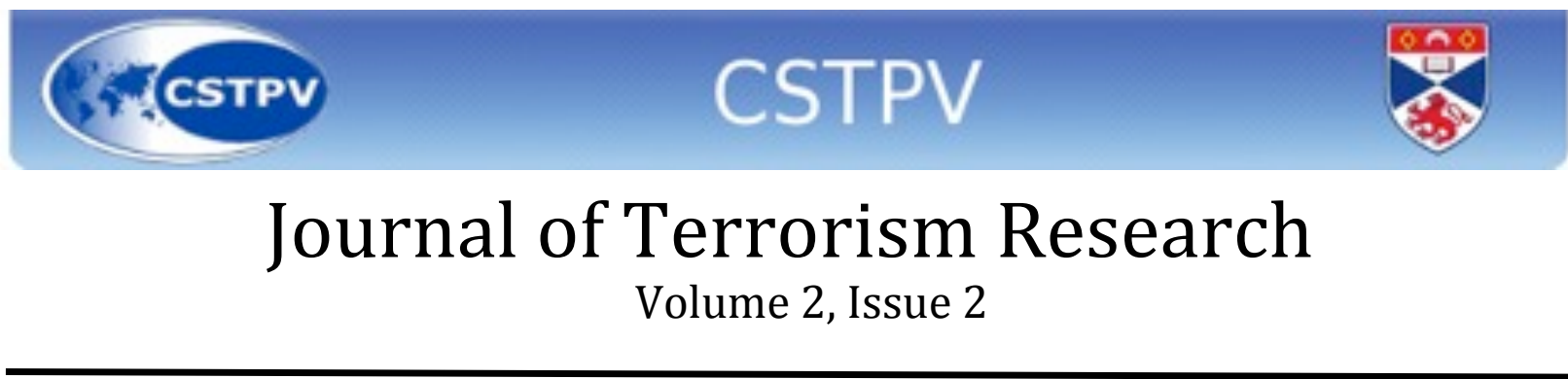

indicators of the pervasiveness and institutionalization of corruption could prove to be more accurate indicators than fluctuations in food consumption, or overall measures of governmental effectiveness or composition.

\section{Conclusion}

The causes of maritime piracy in Somalia are complex and likely based on multiple factors. However, the existing research in this area has repeatedly stressed the importance of governance and drought-related food shortages as important factors fueling the rise of maritime piracy off the Horn of Africa. The tests conducted for this paper suggest that the former is quantitatively sound and the latter is not. This suggests that effective governance is a central component to controlling maritime piracy, and it is vital that a domestic Somali government is rooted in Somali culture and not airlifted in by a Western power from exile.

If maritime piracy off the Somali coast is to be eliminated rather than policed, efforts should be made to encourage homegrown governmental elements that utilize culturally-respected institutions. Incorporating religious institutions and/or clan-based structures would help create a domestically respected governing base. As illustrated in Somaliland, these cultural institutions can successfully compliment and reinforce democratic institutions. Once established these governing institutions can be strengthened and expanded. Such an approach would incorporate the perceived legitimacy and greater efficacy in controlling maritime piracy held by the ICU from 2000-2006, along with the values of representative government found in Somaliland and favored by the West. This combination of structures would create a Somali government that would be both domestically palatable, internationally accepted, and capable of reducing or eliminating maritime piracy operations based in Somalia.

Sam Rohrer is a PhD student at Louisiana State University His primary areas of interest are terrorism, piracy, and the effectiveness of political leaders. 


\section{Journal of Terrorism Research}

Volume 2, Issue 2

\section{Table 1}

World Bank Governance Index

(Average Percentile of World Bank Goverance Indicators)

\begin{tabular}{ll|}
2000 & 0.82 \\
2001 & 2.03 \\
2002 & 3.23 \\
2003 & 1.70 \\
2004 & 0.57 \\
2005 & 0.48 \\
2006 & 0.65 \\
2007 & 0.56 \\
2008 & 0.63 \\
\hline
\end{tabular}

\section{Table 2}

Effects of the Annual World Bank Governance Index (WBGI), the Islamic Courts Union (ICU)/Transitional Federal Government (TFG) Dichotomous Varlable, and the Consumption of Staple Foodstuffs on Reported Quarterly Incidences of Maritime Piracy in East Africa

\begin{tabular}{|c|c|c|}
\hline \multicolumn{3}{|l|}{ Negative Binomicl Regrestion } \\
\hline \multicolumn{3}{|c|}{ Significance of the Model as a Whole } \\
\hline Ukelihood Ratio (UR) Chi-Square & \multicolumn{2}{|c|}{21.47} \\
\hline $\begin{array}{l}\text { Probability that the LR Chi-Squa } \\
\text { the null hypothesis }\end{array}$ & \multicolumn{2}{|l|}{ porierved under } \\
\hline Chl-Bar Square & \multicolumn{2}{|c|}{81.56} \\
\hline Independent Variables & Coefficient(Standard Error) & 2-Score \\
\hline World Bank Governance index & $-0.104(0.171)$ & -0.61 \\
\hline icu & $-1.648\{0.471\}$ & $-3.50 * * *$ \\
\hline Staple Food Consumption & $0.013(0.019)$ & 0.70 \\
\hline \multicolumn{3}{|c|}{ Robust Nogeative Binomial Regression } \\
\hline \multicolumn{3}{|c|}{ Significance of the Model as a Whole } \\
\hline Wald Chi-Square & \multicolumn{2}{|c|}{24.76} \\
\hline $\begin{array}{l}\text { Probubility that the Wald Chi-Sq } \\
\text { the null mypothesis }\end{array}$ & \multicolumn{2}{|l|}{ Is observed under } \\
\hline Independent Variables & Coefficient(Standard Error) & 2-Score \\
\hline World Bank Governance index & $-0.104(0.169)$ & -0.62 \\
\hline icu & $-1.648 \mid 0.438 ;$ & $-3.76 * * *$ \\
\hline Staple Food Consumption & $0.013(0.019)$ & 0.70 \\
\hline
\end{tabular}




\section{Journal of Terrorism Research}

Volume 2, Issue 2

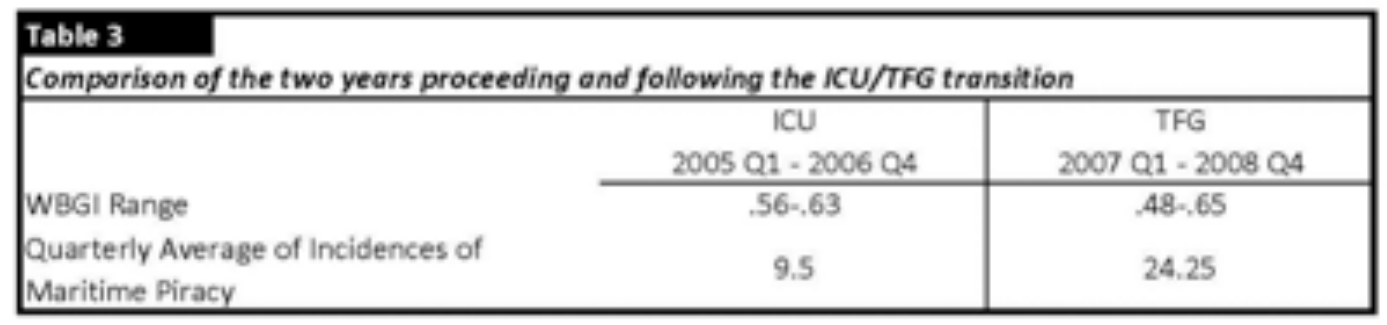

\section{Works Cited}

BBC. (2007, January 1). Somali Islamic Stronghold FAlls. Retrieved November 22, 1009, from http://news.bbc.co.uk/2/hi/africa/6222211.stm

Blomberg, B. S., Hess, G. D., \& Weerapana, A. (2004). Economic Conditions of Terrorism. European Journal of Political Economy, 20 (2), 463-78.

Burgess Jr., D. R. (2008, December 5). The New York Times. Retrieved February 8, 2011, from www.nytimes.com: http:/www.nytimes.com/2008/12/05/opinion/05burgess.html

Chalk, P. (2009). Maritime Piracy: Reasons, Dangers and Solutions. Santa Barbara, CA: Rand Corporation.

DeCaupa, J. (2005, May 9). World Bank Indicators Measure Good Governance. Retrieved November 11, 2009, from http://www.voanews.com/english/archive/2005-05/2005-05-09voa18.cfmCFID $=335659132 \&$ CFTOKEN $=81528905 \&$ jsessionid $=663082 \mathrm{cdb} 5981 \mathrm{~b} 201880731 \mathrm{a}$ $\underline{7 b 7576314 \mathrm{e} 68}$

Finman, B. J. (2007). Maritime Security on the Horn of Africa: Threading the Needle at a Seam of Responsibility. Newport RI: Joint Military Operations Department, Naval War College.

Hanson, S. (2010, January 7). Council on Foreign Relations. Retrieved February 8, 2011, from www.cfr.org: http://www.cfr.org/france/combating-maritime-piracy/p18376

Hastings, J. V. (2009). Geographies of state failure and sophistication in maritime piracy hijackings. Political Geography, 1-11.

Honaker, J. (2008, September 8). Unemployment and Violence in Northern Ireland: A Missing Data Model for Ecological Inference. Retrieved February 10, 2011, from Faculty Profile UCLA: http://tercer.bol.ucla.edu/papers/ni.pdf

Index Mundi. (2009a). Somalia Yearly Corn Domestic Consumption (1000 MT). Retrieved December 12, 2009, from IndexMundi: http://www.indexmundi.com/agriculture/? 


\section{Journal of Terrorism Research}

Volume 2, Issue 2

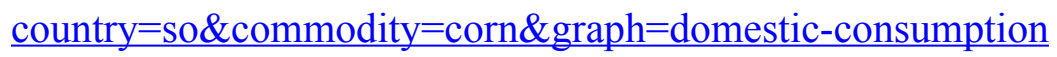

Index Mundi. (2009c). Somalia Yearly Rice, Milled Domestic Consumption (1000 MT).

Retrieved December 19, 2009, from Index Mundi: http://www.indexmundi.com/agriculture/?

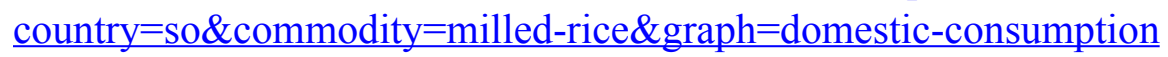

Index Mundi. (2009b). Somalia Yearly Wheat Consumption (1000 MT). Retrieved December 19, 2009, from Index Mundi: http://www.indexmundi.com/agriculture/?

country $=$ So\&commodity $=$ wheat $\&$ graph $=$ domestic-consumption

International Crisis Group. (2005). Somalia's Islamists. Nairobi/Brussels: International Crisis Group.

Lane, K. E. (1998). Pillaging the Empire: Piracy in the Americas 1500-1750. Armonk, NY: M.E. Sharpe.

Lennox, P. (2008). Contemporary Piracy off the Horn of Africa. Calgary, AB: Canadian Defence \& Foreign Affairs Insititute.

Maximo Q. Meija Jr., P. C.-C. (2009). Is maritime piracy random? Applied Economic Letters , 16 (9), 891-5.

McNeill, J., \& Schaefer, B. D. (2009, April 15). Options for Combating Piracy. Retrieved October 1, 2009, from www.heritage.org: http://www.heritage.org/Research/Africa/wm2397.cfm

Moller, B. (2009). Piracy, Maritime Terrorism, and Naval Strategy. Copenhagen, Denmark:

DIIS: Danish Institute for International Studies.

Murphy, M. N. (2007). Contemporary Piracy and Maritime Terrorism. London: International Institute of Strategic Studies.

Murphy, M. (2009). Somali Piracy: Not Just a Naval Problem. Washington DC: Center for Strategic and Budgetary Assessments.

National Security Council. (2008). Countering Piracy off the Horn of Africa: Partnership and Action Plan. Washington DC: National Security Council.

PBS News Hour. (2006, June 8). Islamist Control of Mogadishu Raises Concern of Extremist Future for Somalia. Retrieved November 22, 2009, from http://www.pbs.org/newshour/updates/ africa/jan-june06/somalia_06-08.html

Peterson, S. (2001). Me Against My Brother: At War in Somalia, Sudan, and Rwanda. New York City: Routledge.

Pham, J. P. (2008, September 29). The Challenge of Somali Piracy. Retrieved October 23, 2009, from Atlantic Council: http://www.acus.org/new_atlanticist/challenge-somali-piracy 


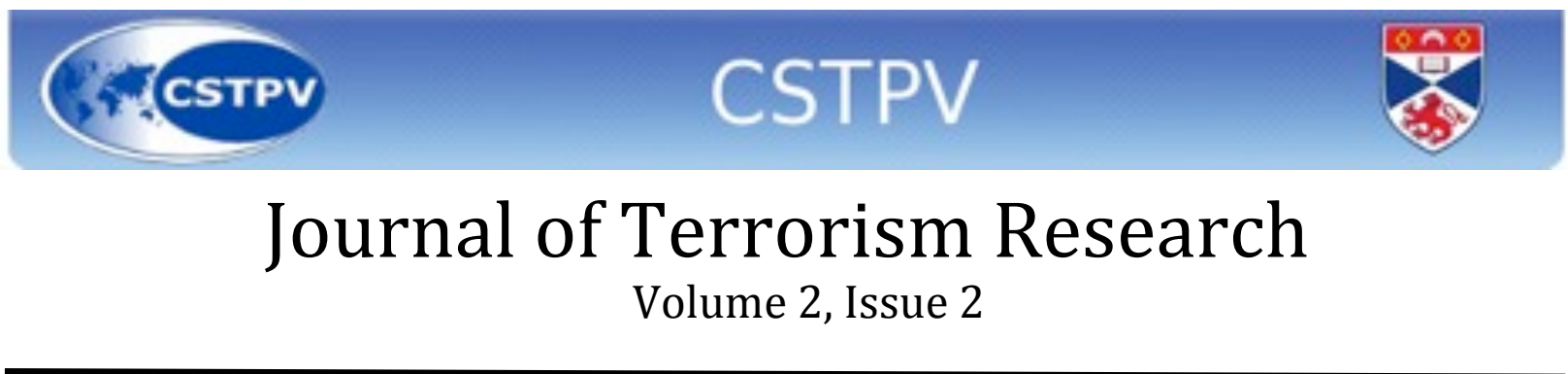

Ploch, L., Blanchard, C. M., O'Rourke, R., Mason, R. C., \& King, R. O. (2009). Piracy off the Horn of Africa. Washington DC: Congressional Research Service.

Ross, S., \& Ben-David, J. (2009). Somali Piracy: An Escalating Security Dilemma. Harvard Africa Policy Journal, Vol. 5 (Spring 2009), 55-70.

\section{Notes}

[1] Maximo Q. Meija Jr., P. C.-C. (2009). Is maritime piracy random? Applied Economic Letters, 16(9), 891-5.

[2] Hastings, J. V. (2009). Geographies of state failure and sophistication in maritime piracy hijackings. Political Geography, 1-11.

[3] Finman, B. J. (2007). Maritime Security on the Horn of Africa: Threading the Needle at a Seam of Responsibility. Newport RI: Joint Military Operations Department, Naval War College.

[4] Murphy, M. (2009). Somali Piracy: Not Just a Naval Problem. Washington DC: Center for Strategic and Budgetary Assessments.

[5] Ploch, L., Blanchard, C. M., O'Rourke, R., Mason, R. C., \& King, R. O. (2009). Piracy off the Horn of Africa. Washington DC: Congressional Research Service.

[6] Ploch, L., Blanchard, C. M., O'Rourke, R., Mason, R. C., \& King, R. O. (2009). Piracy off the Horn of Africa. Washington DC: Congressional Research Service.

[7] Ross, S., \& Ben-David, J. (2009). Somali Piracy: An Escalating Security Dilemma. Harvard Africa Policy Journal, Vol. 5(Spring 2009), $55-70$.

[8] Lennox, P. (2008). Contemporary Piracy off the Horn of Africa. Calgary, AB: Canadian Defence \& Foreign Affairs Insititute.

[9] Lane, K. E. (1998). Pillaging the Empire: Piracy in the Americas 1500-1750. Armonk, NY: M.E. Sharpe.

[10] Moller, B. (2009). Piracy, Maritime Terrorism, and Naval Strategy. Copenhagen, Denmark: DIIS: Danish Institute for International Studies.

[11] Lennox, P. (2008). Contemporary Piracy off the Horn of Africa. Calgary, AB: Canadian Defence \& Foreign Affairs Insititute.

[12] Lane, K. E. (1998). Pillaging the Empire: Piracy in the Americas 1500-1750. Armonk, NY: M.E. Sharpe.

[13] Finman, B. J. (2007). Maritime Security on the Horn of Africa: Threading the Needle at a Seam of Responsibility. Newport RI: Joint Military Operations Department, Naval War College.

[14] McNeill, J., \& Schaefer, B. D. (2009, April 15). Options for Combating Piracy. Retrieved October 1, 2009, from www.heritage.org: http:// www.heritage.org/Research/Africa/wm2397.cfm

[15] International Crisis Group. (2005). Somalia's Islamists. Nairobi/Brussels: International Crisis Group.

[16] Lennox, P. (2008). Contemporary Piracy off the Horn of Africa. Calgary, AB: Canadian Defence \& Foreign Affairs Insititute.

[17] Blomberg, B. S., Hess, G. D., \& Weerapana, A. (2004). Economic Conditions of Terrorism. European Journal of Political Economy, 20(2), 463-78.

[18] Honaker, J. (2008, September 8). Unemployment and Violence in Northern Ireland: A Missing Data Model for Ecological Inference. Retrieved February 10, 2011, from Faculty Profile UCLA: http://tercer.bol.ucla.edu/papers/ni.pdf

[19] Murphy, M. (2009). Somali Piracy: Not Just a Naval Problem. Washington DC: Center for Strategic and Budgetary Assessments.

[20] Chalk, P. (2009). Maritime Piracy: Reasons, Dangers and Solutions. Santa Barbara, CA: Rand Corporation.

[21] International Crisis Group. (2005). Somalia's Islamists. Nairobi/Brussels: International Crisis Group.

[22] PBS News Hour. (2006, June 8). Islamist Control of Mogadishu Raises Concern of Extremist Future for Somalia. Retrieved November 22, 2009, from http://www.pbs.org/newshour/updates/africa/jan-june06/somalia_06-08.html

[23] Ross, S., \& Ben-David, J. (2009). Somali Piracy: An Escalating Security Dilemma. Harvard Africa Policy Journal, Vol. 5(Spring 2009), $55-70$.

[24] Lennox, P. (2008). Contemporary Piracy off the Horn of Africa. Calgary, AB: Canadian Defence \& Foreign Affairs Insititute. 
[25] Murphy, M. (2009). Somali Piracy: Not Just a Naval Problem. Washington DC: Center for Strategic and Budgetary Assessments.

[26] Finman, B. J. (2007). Maritime Security on the Horn of Africa: Threading the Needle at a Seam of Responsibility. Newport RI: Joint Military Operations Department, Naval War College.

[27] Peterson, S. (2001). Me Against My Brother: At War in Somalia, Sudan, and Rwanda. New York City: Routledge.

[28] Ploch, L., Blanchard, C. M., O'Rourke, R., Mason, R. C., \& King, R. O. (2009). Piracy off the Horn of Africa. Washington DC: Congressional Research Service.

[29] National Security Council. (2008). Countering Piracy off the Horn of Africa: Partnership and Action Plan. Washington DC: National Security Council.

[30] Murphy, M. (2009). Somali Piracy: Not Just a Naval Problem. Washington DC: Center for Strategic and Budgetary Assessments.

[31] Burgess Jr., D. R. (2008, December 5). The New York Times. Retrieved February 8, 2011, from www.nytimes.com: http://www.nytimes.com/ 2008/12/05/opinion/05burgess.html

[32] Hanson, S. (2010, January 7). Council on Foreign Relations. Retrieved February 8, 2011, from www.cfr.org: http://www.cfr.org/france/ combating-maritime-piracy/p18376

[33] Ross, S., \& Ben-David, J. (2009). Somali Piracy: An Escalating Security Dilemma. Harvard Africa Policy Journal, Vol. 5(Spring 2009), $55-70$.

[34] Pham, J. P. (2008, September 29). The Challenge of Somali Piracy. Retrieved October 23, 2009, from Atlantic Council: http://www.acus.org/ new atlanticist/challenge-somali-piracy

[35] Hastings, J. V. (2009). Geographies of state failure and sophistication in maritime piracy hijackings. Political Geography, 1-11.

[36] Lennox, P. (2008). Contemporary Piracy off the Horn of Africa. Calgary, AB: Canadian Defence \& Foreign Affairs Insititute.

[37] DeCaupa, J. (2005, May 9). World Bank Indicators Measure Good Governance. Retrieved November 11, 2009, from http:// www.voanews.com/english/archive/2005-05/2005-05-09-voa18.cfm? CFID $=335659132 \&$ CFTOKEN $=81528905 \&$ jsessionid $=663082 \mathrm{cdb5} 981 \mathrm{~b} 201880731 \mathrm{a} 7 \mathrm{~b} 7576314 \mathrm{e} 68$

[38] PBS News Hour. (2006, June 8). Islamist Control of Mogadishu Raises Concern of Extremist Future for Somalia. Retrieved November 22, 2009, from http://www.pbs.org/newshour/updates/africa/jan-june06/somalia 06-08.html

[39] BBC. (2007, January 1). Somali Islamic Stronghold Falls. Retrieved November 22, 1009, from http://news.bbc.co.uk/2/hi/africa6222211.stm

[40] Lennox, P. (2008). Contemporary Piracy off the Horn of Africa. Calgary, AB: Canadian Defence \& Foreign Affairs Insititute.

[41] Index Mundi. (2009a). Somalia Yearly Corn Domestic Consumption (1000 MT). Retrieved December 12, 2009, from IndexMundi: http:// www.indexmundi.com/agriculture/?country=so\&commodity=corn\&graph=domestic-consumption

[42] Index Mundi. (2009b). Somalia Yearly Wheat Consumption (1000 MT). Retrieved December 19, 2009, from Index Mundi: http:// www.indexmundi.com/agriculture/?country $=$ so \&commodity=wheat $\& g r a p h=$ domestic-consumption

[43] Index Mundi. (2009c). Somalia Yearly Rice, Milled Domestic Consumption (1000 MT). Retrieved December 19, 2009, from Index Mundi: http://www.indexmundi.com/agriculture/?country=so\&commodity=milled-rice\&graph=domestic-consumption 